\title{
COMMENTS ON THE PAPER BY SAM MOYO
}

\author{
Stefaan MARIJSSE \\ Centre for Development Studies \\ Universitaire Faculteiten Sint-Ignatius Antwerpen \\ Prinsstraat 13 \\ 2000 Antwerpen
}

I have been reading working papers from Sam Moyo for quite some time and reading this last one was at first sight rather surprising. Sam Moyo appears to be a late convert to what he had criticised earlier, namely, the World Bank strategy. Indeed, what he is propagating is a "redistribution with growth" strategy. This was a strategy very much in fashion in the 70 s and divulgated by people like Hollis Chenery and other authors of the "think tank" of the World Bank. And with exactly the same arguments and examples that they used to underpin their arguments, namely South Korea and Taiwan. The basic arguments of these authors and now also of Sam Moyo were that export-led growth, combined with asset redistribution, meaning land redistribution, creates not only a higher per capita income, but also a comparatively more egalitarian income distribution.

Since I called Sam Moyo a late convert, I must confess that the same label could be used for me, although my conversion process has other roots. In Sam Moyo's analysis, it seems to spring out of the ambiguity and the tension in Zimbabwe, between socialist talk and economic reality, where he states: "At the moment this strategy is not transformation to socialism but more simply a shift from import substitution and industrialisation to export-led growth within a basically capitalist organisation of production." 
His main thesis is that land reform must be argued within this perspective, not as an alternative, but as a complementary strategy. I agree with this perspective, but I would also like to add that this is probably the most realistic strategy towards more social equity. If this is true, then the question is: is the divorce between socialist talk and the economic reality that big? I could paraphrase a famous saying from Philippe Van Parijs, arguing long before the events in Eastern Europe, that the fastest way to socialism is capitalism, provided a firm commitment to distributive and participative justice is guaranteed. The question is whether that commitment is real in Zimbabwe.

My conversion sprang out of a very different experience. I have been, as an outsider, looking at the Nicaraguan experience and that of Zimbabwe for some ten years. Both countries went at the same time through a liberation struggle; they had both powerful neighbours, constraining their degrees of freedom; both countries use the same ideological discourse of transformation to socialism; and they started in 1980 with comparable economic structures, namely: they had about the same level of income per head, the industrial structure was largely the same, based on transformation of agricultural produce.

After 10 years of political independence Nicaragua's income has fallen by a third, whilst Zimbabwe's has risen roughly by a third. The explanations of these different results lead me to make some comments on Sam Moyo's paper that may nuance or strengthen a lot of the points made by him.

1. Whereas the Nicaraguan government completely and abruptly changed the relative price structure, favouring the urban classes, by heavily subsidizing consumer goods, the Zimbabwean government did not alter the relative price structure very much, but merely abolished the impediments of the market entry for peasants producers. This has resulted in a well known boost to the traditional crops. This favourable price structure for peasant producers is in Africa outstanding and a unicum in post-independence, with maybe the exception of Ivory Coast and Kenya for certain crops. It cannot be enough stressed that this favourable price structure for peasants is one of the big performances of the Zimbabwean government.

2. Nicaragua embarked on a massive redistribution of land. More than $25 \%$ of the land was redistributed. It was redistributed in the beginning especially to the state sector and to collective cooperatives. Individual land titles were very reluctantly given and only under pressure of military situations. This was because of the idea that peasant producers can never be competitive with, say, large-scale commercial farmers. Dispersing land into small plots would, in the opinion of the leaders of Nicaragua, lower the agricultural production. Especially the refusal to redistribute under individual land titles was one cause of complete disorganisation of the 
agricultural sector. Another cause was the fact that the exchange rate was extremely overvalued in Nicaragua. At a certain moment one gallon of gasoline was much cheaper than a piece of watermelon. Such an overvaluation of the exchange rate is a perfect disincentive to export and a perfect incentive to import products. Not only did you have a complete disorganisation of the export sector, but at the same time a boost of the imports.

None of these happened in Zimbabwe, because of the very cautious policy of the Zimbabwean government.

Given these differences, does this mean that I am now having a plea for a policy in Zimbabwe for doing more of the same ? It might seem at first sigth, but it is not at all the case. What I would argue is that the policy followed by the Zimbabwean government in these first 10 years was probably the most correct one. But this policy has been stretched as far as possible and I think that time has come to reformulate the land reform to urge for more land redistribution in the future because, if there is not a change in the future policy of land reform, you will see an exacerbation of inequality. I can illustrate this point with some research that I and others have been carrying out in the Mutoko communal area, which is situated in the third and the fourth natural region. We found during our research, carried out from 1985 to 1988 , that the government stimulated peasant producers by good producer prices, by access to credit, access to extension services at a scale never experienced in Africa before. After a few years it became very obvious that only 10 to mostly $20 \%$ of the peasants could respond quickly by boosting their production but at the same time leaving behind, in terms of agricultural production and income, the majority of peasant producers in these communal areas, who reaped only small benefits of the easier entry into the market. This is of course not new, it is the traditional story of diversification that takes place when development opportunities are created. At the same time this creates an excessive basis of income inequality. The income inequality in one communal area is, e.g. in terms of the Gini coefficient, higher than for the whole country. The question is than: how does it come that this diversification, this income inequality, is becoming so important in the communal areas ? Out of a regression analysis we learnt that there was a variety of reasons for the variance in agricultural income and thus the phenomenon of some becoming richer and others becoming poorer, such as:

- good farming practices: those with good experiences in farming did have higher incomes;

- access to markets: if you are close to a market, you can of course sell your production much more easily; 
- availibility of labour: if you have a big family and you can draw on family labour, especially women, then you are better off;

- membership of certain types of cooperatives, which has been stressed by Michael Bratton.

But we found that the single and most explanatory variable was access to land. Almost $30 \%$ of all the variance in income was explained in terms of mere quantity of land. If this is true for all communal areas, it means that access to land for the peasant sector stays the single and most prominent key not only for boosting production but even more so for equity reasons. Therefore, the meagre policies of land redistribution, spending only some $1 \%$ of total budget for acquiring land, should be reinforced in future.

I have some further questions.

The study was sometimes conducted in too massive terms. What is needed for the discussion is:

- what products can be produced by small farmers productively;

- what products are more suited for the large-scale commercial farming sector;

- how productive can these peasant farmers be under what circumstances?

We do not have enough research on that. Instead of having a division between agricultural department and political economy, there should be much more cooperation between these two disciplines. This split, also in the ministries, between land resettlement and agriculture, also occurs in the academic sphere between political economists and agronomists. I think that this is a pity.

A second point: resettlement, land redistribution, physical redistribution of land not sustained by a lot of other policy measures will not produce very good results. Therefore I think that the cautious way of the Zimbabwean government in the past was good and they adapted also very fast to changes, e.g. in the collective schemes etc.

I have a few points on political economy. Is the National Farmers' Association of Zimbabwe the right channel to voice the interests of the peasants ? My question is: 
in the future, whatever the government will be - and it is not so important what government you have, because as you said, right-wing governments can also implement land reforms - how can you have the empowerment of peasants, how can it be enhanced, what are the adapted structures to achieve it? In Zimbabwe you have a very top-down kind of structure. Is this the right structure? 